\title{
THE CURRENT NORTHERNMOST BREEDING PAIR OF THE CALIFORNIA GNATCATCHER
}

\author{
MICHAEL C. COUFFER, Grey Owl Biological Consulting, 716 Marguerite Avenue, \\ Corona del Mar, California 92625; mikecouffer@gmail.com
}

During the spring of 2015, I documented a pair of California Gnatcatchers (Polioptila californica californica) nesting in the foothills of the San Gabriel Mountains of Los Angeles County, in Grasshopper Canyon north of the town of Castaic and west of Castaic Lake. I located one pair with three dependent juveniles and three nests: one nest from a previous year, one recently active nest, and one nest built and occupied during the observation period. I found these gnatcatchers $13.8 \mathrm{~km}$ north of the northernmost pair of the California Gnatcatcher previously reported to the United States Fish and Wildlife Service (USFWS; data available by request to the offices in Ventura or Carlsbad, California).

Polioptila californica californica is designated as threatened by the USFWS and as a species of special concern by the California Department of Fish and Wildlife. Its four component subspecies extend from southwestern California to southern Baja California, Mexico (Mellink and Rea 1994, Atwood and Lerman 2006). The most northerly subspecies, nominate californica, is an obligate resident of coastal sage scrub in Los Angeles, Orange, Riverside, and San Diego counties, California, and northwestern Baja California (Atwood 1992). The breeding season for californica ranges from mid-February to July. Nests are constructed of various soft materials, about $1 \mathrm{~m}$ off the ground, in shrubs such as California bush sunflower (Encelia californica), California sagebrush (Artemisia californica), black sage (Salvia mellifera), and white sage (S. apiana). The California Gnatcatcher has been recorded from sea level to approximately $914 \mathrm{~m}$ above mean sea level (USFWS 2003), although >90\% of records are at elevations $<550 \mathrm{~m}$ (Atwood and Bolsinger 1992). In 2001, the USFWS estimated the size of the population in southern California to be about 3000 pairs (Atwood and Bontrager 2001).

Cooper et al. (2017) summarized reports of the California Gnatcatcher at the northern limit of its range, and the locations they mapped included the site of the pair I observed in 2015. Formerly, the species was common from the San Fernando Valley east along the base of the San Gabriel Mountains to Claremont (Atwood 1990). Today, however, it is rare in the northern part of its range with only occasional sightings from Santa Clarita to Tujunga Wash, though a small population persists near the city of Moorpark in Ventura County (Cooper et al. 2017). Until July 2015, the northernmost pair reported to the USFWS was located west of the Magic Mountain amusement park just west of the city Santa Clarita and south of the Santa Clara River (USFWS unpubl. data). An adult male and female were observed foraging at that location during the 2012 breeding season, but no breeding behavior, nests, or immature birds were seen.

In April of 2014, a team of biologists following the current protocol (USFWS $1997 \mathrm{a}, \mathrm{b})$ conducted focused presence/absence surveys for the California Gnatcatcher across 538 hectares within Grasshopper Canyon west of Castaic Lake in Los Angeles County, north of the Santa Clara River. The results of these surveys are available at http://planning.lacounty.gov/assets/upl/case/tr073336_dseir-appen-d. pdf (pp. 473-495). A female was observed twice within the Grasshopper Canyon drainage approximately $1 \mathrm{~km}$ west of the western shore of Castaic Lake and $4.5 \mathrm{~km}$ northwest of the lake's main dam. An adult male was detected once $3 \mathrm{~km}$ southeast of the female, down the canyon. No nesting behaviors were observed, and the birds were not relocated during subsequent surveys.

A year later, on 25 April 2015, another gnatcatcher-permitted biologist and I began 


\section{NOTES}

surveying this site under the federal protocol. The survey results are available at http:// planning.lacounty.gov/assets/upl/case/tr073336_dseir-appen-d.pdf (pp. 496-515, 517) and in Cooper et al. (2017). Under the protocol, all potentially occupied habitat must be surveyed six times within the breeding season, and my assigned survey area took six daily visits to cover each week. On 3 May, I located an adult male California Gnatcatcher a few meters from where a female had been detected the previous year (Figure 1). The male soon joined an adult female. At that time the birds showed little reaction to broadcast of the species' calls. After completing surveys within the area planned for the morning, I returned to the site to determine the pair's nesting status and found the pair tending three dependent juveniles that did not forage for themselves. The behavior of the juveniles indicated that they had emerged from a nearby nest. When they were near the juveniles, the adults reacted strongly to a very brief playing of the call.

On 13 May, I was following the movements of the male when it flew to a shrub and settled for a few seconds into a nest (Figure 2). The nest was empty and in excellent condition but worn inside from use. The nest was situated in a black sage at an elevation of $560 \mathrm{~m}$ above mean sea level on a gradual slope of about a $20 \%$ gradient, $100 \mathrm{~m}$ east of the bottom of Grasshopper Canyon. Shrubs within $15 \mathrm{~m}$ of the nest were $65 \%$ black sage, 25\% thickleaf yerba santa (Eriodictyon crassifolium), and 10\%

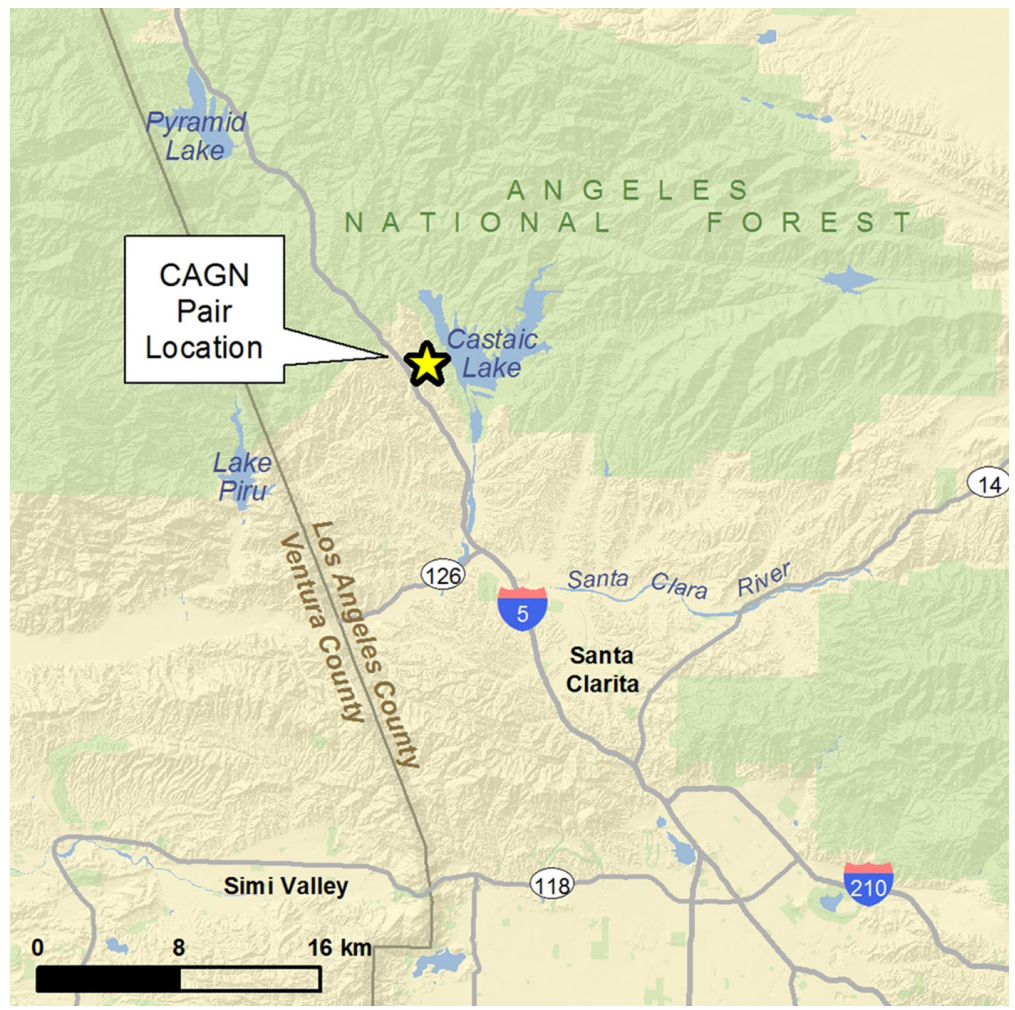

Figure 1. Location of California Gnatcatchers nesting in Grasshopper Canyon, Los Angeles County, California. 


\section{NOTES}

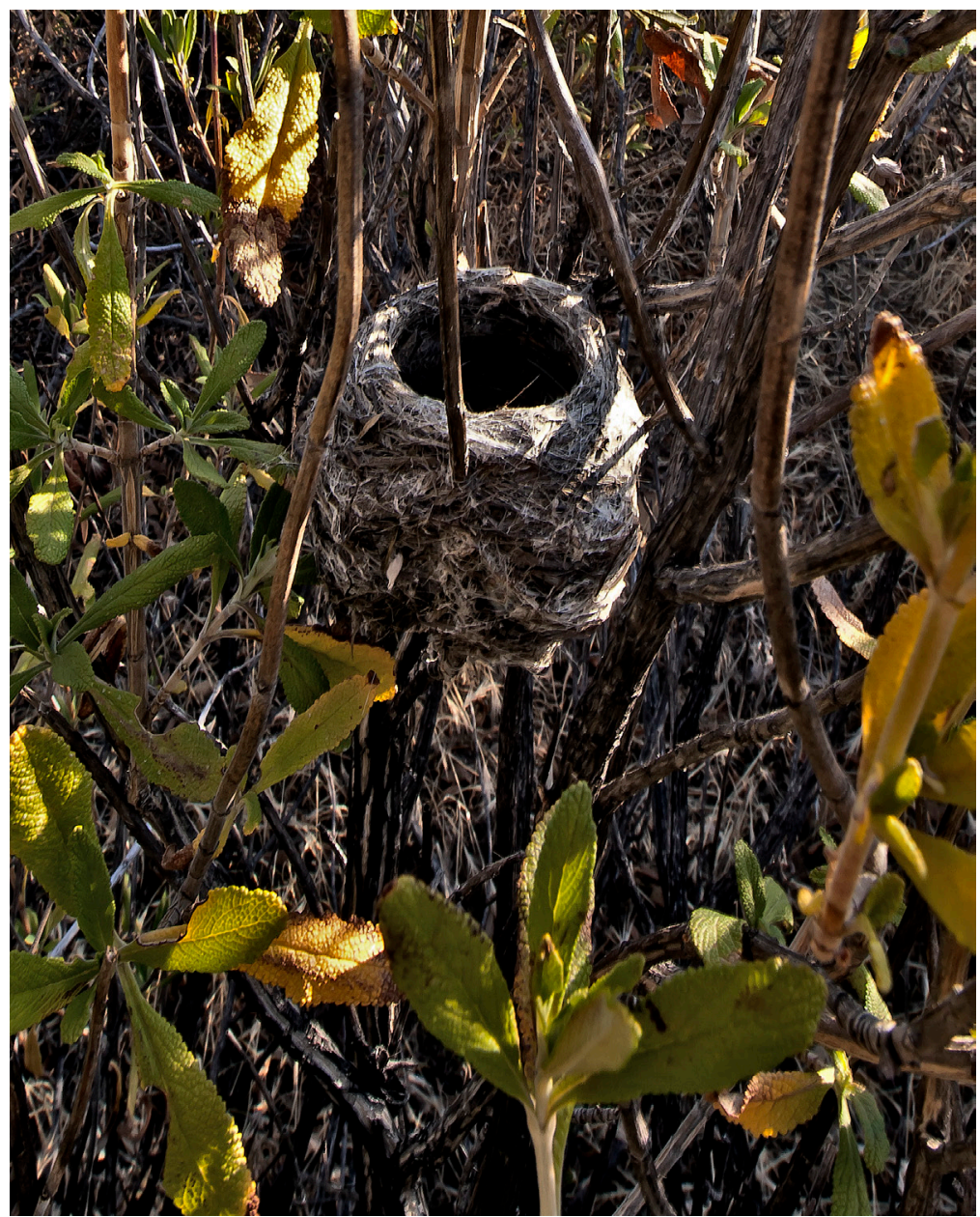

Figure 2. California Gnatcatcher nest located 13 May 2015 from which three juveniles had previously fledged.

Photo by Michael C. Couffer

California sagebrush. Given that the male visited this nest, that the nest had been recently used, and that it was within the pair's home range, I concluded that this was the nest from which the three juveniles had emerged.

After the male perched in its previous nest, it foraged on the slope of a side canyon immediately south of the nest, then flew up the canyon to join the female and three juveniles. The juveniles foraged on their own but occasionally begged and received food from both adults. The shrub cover within about $15 \mathrm{~m}$ of the juveniles consisted of approximately $70 \%$ black sage, $20 \%$ thickleaf yerba santa, and 10\% purple sage (Salvia leucophylla).

It has been my experience that during a single nesting season, after the first nesting 


\section{NOTES}

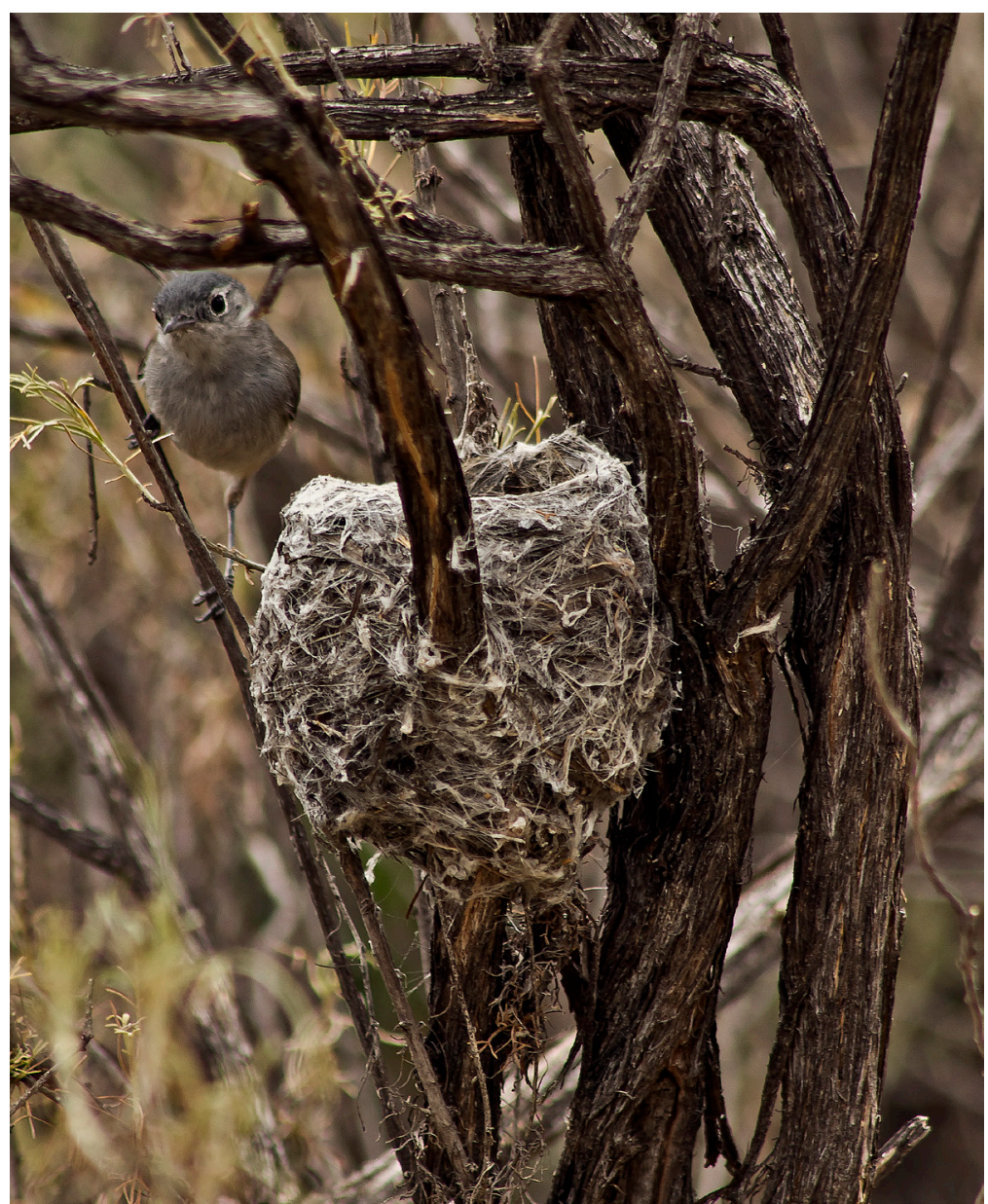

Figure 3. Female California Gnatcatcher at the nest in Grasshopper Canyon, Los Angeles County, first located on 27 May.

Photo by Michael C. Couffer

is completed, a California Gnatcatcher pair often builds subsequent nests by reusing material torn from their previous nest. On the morning of 27 May I found that one side of the apparently successful nest was missing, a strong indication that the pair was using the material to build a new nest. I confirmed this later when the male flew from the old nest carrying material torn from the nest up the side canyon where I had found the family group on 13 May-additional evidence that the nest in which the male had briefly perched was the nest that had produced the three juveniles. Soon thereafter, I found the female lining a newly constructed nest in the middle of a California sagebrush (see this issue's inside front cover; Figure 3). The nest was near the bottom of 


\section{NOTES}

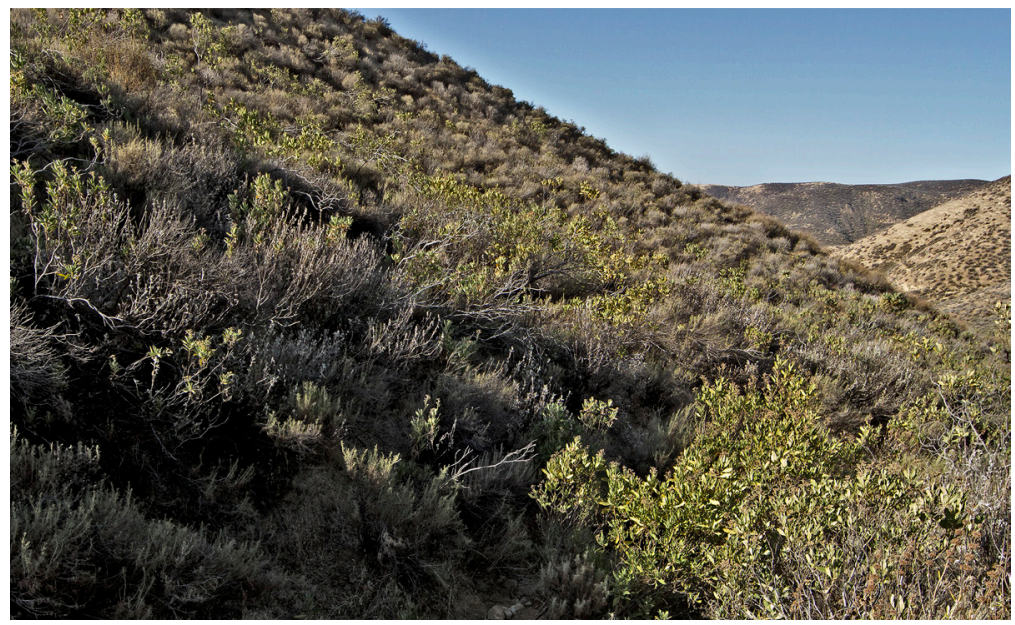

Figure 4. Habitat in Grasshopper Canyon, Los Angeles County, in which California Gnatcatchers nested.

Photo by Michael C. Couffer

the side canyon at an elevation of $577 \mathrm{~m}$ and was located near the center of habitat shown in Figure 4. The shrub cover within $15 \mathrm{~m}$ of the new nest was composed of approximately 50\% California sagebrush, 35\% thickleaf yerba santa, 10\% black and purple sage, and $5 \%$ bare ground with sparse annual grasses. No juvenile California Gnatcatchers were observed during this survey or subsequent visits.

A week later, both adults took turns on the nest, making several nest exchanges and behaving as if eggs were in the nest. Then in the late afternoon of 8 June, I watched the nest with binoculars from a distance. I saw no adults initially, but after about 15 minutes the female flew in and sat in the nest for about 10 minutes before flying off. I continued watching the nest from a distance for just over a half an hour but no adults appeared at the nest. The ambient temperature in the shade that day had reached $38^{\circ}$ $\mathrm{C}$, and although the afternoon temperature had dropped, the lack of adults attending to eggs or young nestlings indicated a problem; neither eggs nor young nestlings of the California Gnatcatcher should remain untended for that amount of time. Being federally permitted to inspect the contents of this species' nests, I approached the nest and found two eggs of the gnatcatcher and three of the Brown-headed Cowbird (Molothrus ater), a nest parasite. To increase the chances of successful nesting, I removed the cowbird eggs with double-sided tape.

On 12 June, both adults appeared to be incubating eggs with nest exchanges taking place. Because the nest had been parasitized, I approached it while both adults were off foraging and found an old nest from a previous year in a California sagebrush just $5 \mathrm{~m}$ from the currently active nest. The old nest had fallen into ruin, with one side missing, but remained identifiable as a California Gnatcatcher nest. The recently built nest still held two gnatcatcher eggs and no cowbird eggs. On 26 June, I concluded that the nest was abandoned, as it still contained the two gnatcatcher eggs but no adults tended to it. The adults foraged together within the habitat where I had previously observed them. Although this second nest had failed, the pair had fledged three young from this territory earlier in 2015.

Some may consider surveys for the California Gnatcatcher within and north of 


\section{NOTES}

the Santa Clarita Valley to be a waste of resources, as very few breeding pairs have been found in that area during focused surveys, and many of the sightings have been of single birds seen only once. However, the detection of a juvenile California Gnatcatcher near Gorman in Los Angeles County by Brian E. Daniels (Cooper et al. 2017) highlights the questions of how far north the species currently breeds and how climate change might affect its breeding range. The detection of this breeding pair of California Gnatcatchers west of Castaic Lake, as well as occasional sightings of scattered birds to the south along the foothills of the San Gabriel Mountains, suggests that the USFWS and consulting biologists' recommendations for surveys for breeding California Gnatcatchers in the Santa Clarita Valley and the foothills of the San Gabriel Mountains are warranted.

I am grateful to Mark A. Pavelka, formerly of the U. S. Fish and Wildlife Service, Daniel S. Cooper, and Robert A. Hamilton for providing valuable editorial suggestions on manuscript drafts.

\section{LITERATURE CITED}

Atwood, J. L. 1990. Status review of the California Gnatcatcher (Polioptila californica). Manomet Bird Observatory, Manomet, MA.

Atwood, J. L. 1992. Rare, local, little-known, and declining North American breeders-A closer look. Birding 25:228-233.

Atwood, J. L., and Bolsinger, J. S. 1992. Elevational distribution of California Gnatcatchers in the United States. J. Field Ornithol. 63:159-168.

Atwood, J. L., and Bontrager, D. R. 2001. California Gnatcatcher (Polioptila californica), in The Birds of North America (A. Poole and F. Gill, eds.), no. 574. Birds N. Am., Inc., Philadelphia; doi 10.2173/bna.574.

Atwood, J. L., and Lerman, S. B.. 2006. Family Polioptilidae (gnatcatchers), in Handbook of the Birds of the World (J. del Hoyo, A. Elliott, and D. A. Christie, eds.), . vol. 11, pp. 350-377. Lynx Edicions, Barcelona.

Cooper, D. S., Mongolo, J., and Dellith, C. 2017. Status of the California Gnatcatcher at the northern edge of its range. W. Birds 48:124-140; doi 10.21199/ WB48.2.3.

Mellink, E., and Rea. 1994, A. M. Taxonomic status of the California Gnatcatchers of northwestern Baja California, Mexico. W. Birds 25:50-62.

U.S. Fish and Wildlife Service (USFWS). 1997a. Coastal California Gnatcatcher (Polioptila californica californica) presence/absence survey guidelines February 28, 1997; www.fws.gov/ventura/docs/species/protocols/cagn/coastalgnatcatcher_survey-guidelines.pdf.

U.S. Fish and Wildlife Service (USFWS). 1997b. Coastal California Gnatcatcher (Polioptila californica californica) presence/absence survey protocol revisedJuly 28, 1997; www.fws.gov/cno/es/Recovery_Permitting/birds/coastal_calif_ gnatcatcher/CoastalCaliforniaGnatcatcher_SurveyGuidelines_19970728.pdf.

U.S. Fish and Wildlife Service (USFWS). 2003 (April 24). Designation of critical habitat for the Coastal California Gnatcatcher (Polioptila californica californica) and determination of distinct vertebrate population segment for the California Gnatcatcher (Polioptila californica); proposed rule. Federal Register 68(79):2022820312; http://policy.fws.gov/ library/039435.pdf.

Accepted 17 June 2019 